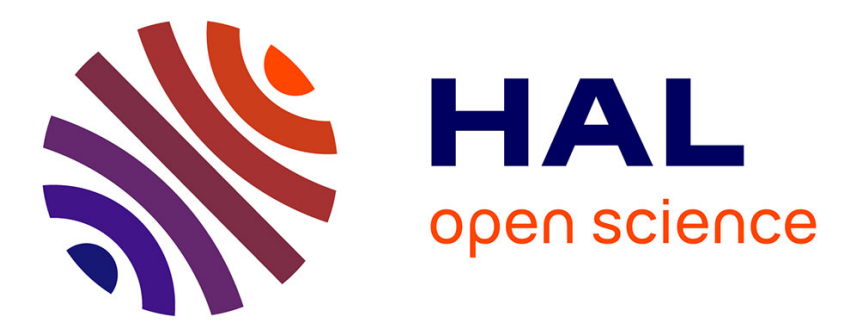

\title{
Acute Tramadol Administration Induces the Expression of pERK1/2 in Different Limbic and Pain Processing Structures
}

\author{
Hend Omara-Reda, Omar Ouachikh, Franck F Durif, Aziz Hafidi
}

\section{To cite this version:}

Hend Omara-Reda, Omar Ouachikh, Franck F Durif, Aziz Hafidi. Acute Tramadol Administration Induces the Expression of pERK1/2 in Different Limbic and Pain Processing Structures. Chronic Pain \& Management, 2020, 4 (2), pp.1-8. 10.29011/2576-957X.100030 . hal-03183915

\author{
HAL Id: hal-03183915 \\ https://hal.uca.fr/hal-03183915
}

Submitted on 31 Mar 2021

HAL is a multi-disciplinary open access archive for the deposit and dissemination of scientific research documents, whether they are published or not. The documents may come from teaching and research institutions in France or abroad, or from public or private research centers.
L'archive ouverte pluridisciplinaire HAL, est destinée au dépôt et à la diffusion de documents scientifiques de niveau recherche, publiés ou non, émanant des établissements d'enseignement et de recherche français ou étrangers, des laboratoires publics ou privés.

\section{(1)(1) $\$(0)$}

Distributed under a Creative Commons Attribution - NonCommercial - ShareAlikel 4.0 


\title{
Chronic Pain and Management Journal
}

\section{Acute Tramadol Administration Induces the Expression of pERK1/2 in Different Limbic and Pain Processing Structures}

\section{Hend Omara-Reda, Omar Ouachikh, Franck Durif, Aziz Hafidi*}

Laboratoire de Neuropsychopharmacologie des systèmes dopaminergiques sous corticaux, Université Clermont Auvergne, France

"Corresponding author: Aziz Hafidi, Laboratoire de Neuropsychopharmacologie des systèmes dopaminergiques sous corticaux, EA7280. Université Clermont Auvergne, CHRU Clermont-Ferrand, Clermont-Ferrand, 63000, France

Citation: Omara-Reda H, Ouachikh O, Durif F, Hafidi A (2020) Acute Tramadol Administration Induces the Expression of pERK1/2 in Different Limbic and Pain Processing Structures. Chron Pain Manag 4: 130. DOI: 10.29011/2576-957X.100030

Received Date: 05 August, 2020; Accepted Date: 26 August, 2020; Published Date: 31 August, 2020

\begin{abstract}
Tramadol is a painkiller with some abuse potentials. The current study aimed to investigate rat cerebral structures that were activated by acute intraperitoneal administration of tramadol $(10 \mathrm{mg} / \mathrm{kg})$. The expression of $\mathrm{pERK} 1 / 2$ was used as a molecular tool for tramadol-induced neuronal activation in the brain. Tramadol induced a differential $p E R K 1 / 2$ labeling expression in the brain. A robust pERK1/2 expression was present in limbic, motor, and pain processing structures when compared to others. pERK1/2 labeling was observed in somatosensory, motor, insular cingulate cortex, hippocampus, amygdala, thalamus, habenula, and striatum. Descending pain-processing structures such as periventricular hypothalamus nucleus, periaqueductal grey, dorsal raphe, and rostral ventromedial medulla presented also a high pERK1/2 expression. In medullary and spinal dorsal horns, pERK $1 / 2$ was highly expressed principally in superficial laminae (outer lamina II and lamina I) which processes pain. These results are following the reinforcing, motor, and pain effects of tramadol.
\end{abstract}

Keywords: Pain; Addiction; Tramadol, pERK1/2; Neuronal activation

\section{Introduction}

Tramadol an opioid agonist commonly used alone or as co-medication for chronic pain. It constitutes one of the most chosen analgesic opioids in many pharmacopeias [1]. It provides analgesia through a dual mechanism of action: one through the activation of opioid receptors and a second through its inhibition of central monoaminergic reuptake, which increases brain levels of monoaminergic neurotransmitters [2,3]. In this way, Tramadol has also an antidepressant action [4]. Tramadol acts on different receptors and ion channels (GABAA, glycine, NMDA, adrenergic, nicotinic acetylcholine, sodium channels) [3-8].

Different clinical and preclinical studies revealed an abuse effect of tramadol [9-28].

The Extracellular Signal-Regulated Kinase (ERK) is a component of the Mitogen-Activated Protein Kinase (MAPK) cascade. They are involved in relaying extracellular signals into intracellular responses. They play different functions in the brain especially in synaptic plasticity, learning, and memory, addiction, and pain [29-31]. The phosphorylation of ERK1/2, which constitutes their activation, plays an important role in pain [31].
This phosphorylation is induced in different peripheral and central brain structures as a response of noxious stimuli or in inflammatory and neuropathic pain situations. Alternatively, exposure to a variety of substances (alcohol, amphetamine, and cocaine, nicotine), with abuse potential induced the phosphorylation of ERK $1 / 2$ in the different brain structures [32-36]. The phosphorylation of ERK1/2 may promote the drug's rewarding effects.

In light of the above, the current study aimed to investigate the expression of the phosphorylate pERK $1 / 2$ in the brain upon acute peritoneal administration of tramadol in the rat. Specific interest was given to addiction and pain processing structures. This is the first study evaluating pERK1/2 expression in brain regions of tramadol-treated rats. The immunohistochemical method was used to achieve this goal.

\section{Materials and Methods}

Animals

Twelve adult Sprague Dawley rats (Charles Rivers, L'Arbresle, France) were used. Rats were maintained in a controlled environment (lights on 07:00-19:00 h, $22^{\circ} \mathrm{C}$ ) with $a d$ libitum access to food and water. The experiments followed the ethical guidelines of the animal ethics committee of the University of Auvergne (APAFIS\#19965-20190325052285). 


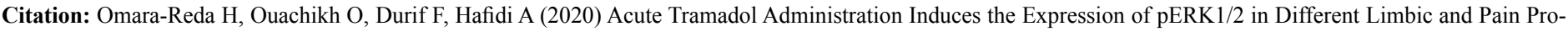
cessing Structures. Chron Pain Manag 4: 130. DOI: 10.29011/2576-957X.100030

Tramadol dissolved in saline $(10 \mathrm{mg} / \mathrm{kg})$ was intraperitoneally administrated to the rats $(n=6)$. A control group $(n=6)$ was injected with saline. Four minutes after tramadol or saline injections. Rats were deeply anesthetized with $1 \%$ ketamine and Xylazine. All rats (control and tramadol injected) were perfused through the heart with saline followed by $4 \%$ paraformaldehyde in PhosphateBuffered Saline (PBS). Brains were then removed and placed in $30 \%$ sucrose and $0.05 \%$ sodium azide solution overnight at $4^{\circ} \mathrm{C}$. Coronal sections $(30 \mu \mathrm{m})$ were obtained using a freezing microtome and collected in $0.05 \mathrm{M}$ Tris-Buffered Saline (TBS). Free-floating sections were placed in $1 \%$ normal goat serum for $1 \mathrm{~h}$ before overnight incubation in primary polyclonal antibody solution (anti-pERK1/2 antibody, 1:500, rabbit, Ozyme, France). After several rinses, sections were incubated with a secondary antibody (1:400 for goat anti-rabbit Cy3; Vector Lab, France) for $3 \mathrm{~h}$ at room temperature. All antibodies were diluted in TBS containing $0.25 \%$ bovine serum albumin and $0.3 \%$ TritonX-100. The sections were finally rinsed in TBS, mounted onto gelatincoated slides, dehydrated in alcohol, cleared in xylene, and cover-slipped with distyrene-plasticizer-xylene. The specificity of the immunostaining was assessed by pERK $1 / 2$ protein preadsorbed antibody $(0.25 \mu \mathrm{g} / \mu \mathrm{l}$, Proteintech, United Kingdom; 24 hours before use), which resulted in the absence or a reduced signal. Some control experiments were done by substitution of the primary antibody with rabbit or mouse serum resulting in the absence of staining. For double staining, sections were incubated simultaneously with primary antibodies anti-pERK $1 / 2$ and antiPKCg antibody (1:5000 mouse anti-PKCg, Sigma-Aldrich, France) and corresponding $\mathrm{Cy} 2$ rabbit anti-mouse secondary antibody (Victor lab, France) as described previously [37,38]. Photomicrographs of immuno-stained sections were captured and image intensity analysis was completed using ImageJ software (ImageJ v1.41, National Institute of Health, USA).

\section{Results}

The current study focused on structures having robust staining and that are implicated in addiction and pain. Thus, differential expression of pERK1/2 was observed in the brain with some structures having robust labeling while others presenting a less prominent one.

A differential pERK1/2 staining was observed within the cerebral cortex (Figure 1A) with some cortices having robust staining while others presenting a less intense one. Intense labeling is highlighted by an increase in the labeling signal and its presence in the dendritic processes (Figure 1B). Less intense labeling corresponded to a lower intensity of the labeling that was mostly restricted to cell stomata (Figure 1C). Intense pERK1/2 labeling was observed in cortices that included primary and secondary motor cortex, somatosensory cortex, insular cortex, primary and secondary visual cortex, anterior cingulate cortex, primary and secondary auditory cortex, parietal association cortex, temporal association cortex, perirhinal cortex, and entorhinal cortex.

In the hippocampus, intense pERK1/2 labeling was observed in all subdivisions (CA1, CA2, CA3, CA4, and DG dentate gyrus). Intense $\mathrm{pERK} 1 / 2$ was observed in granule cells of the DG (Figure 1D) and in virtually all pyramidal cells of CA1, CA2, and CA3 (Figure 1F) in addition to another neuronal cell type.
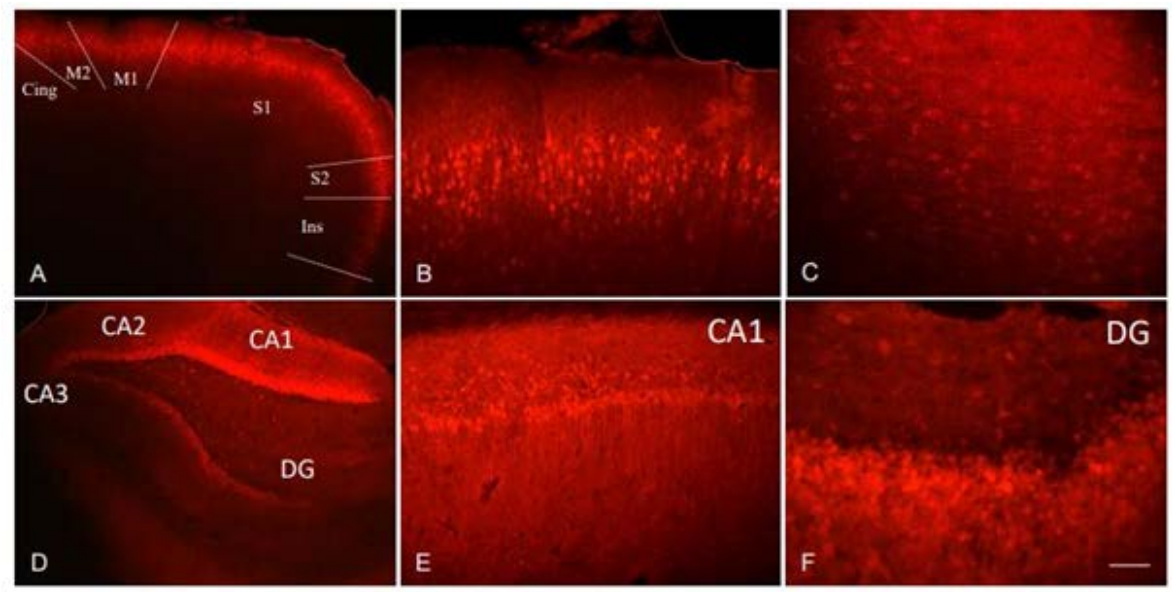

Figure 1: A Micrograph showing the expression of pERK1/2 labeling in the cortex and the hippocampus. Intense $p E R K 1 / 2$ is observed in the cortex (A). At high magnification, very intense labeling is present within neuronal cell bodies and processes. Some of pERK1/2 positive cells are pyramidal cells (B). The labeling is located within the cell body and dendritic processes. In other cerebral cortices, a weak pERK1/2 labeling is present in cell somata only (C). In the hippocampus, intense pERK1/2 labeling is observed in all hippocampal subdivisions. Intense pERK1/2 is located in virtually all pyramidal cells of CA1, CA2, and CA3 (Figure 1D) and in granule cells of the dentate gyrus (DG) (Figure 1F). Cing: cingulate cortex, M1/M2 primary, and secondary motor cortex, S1/2: primary and secondary somatosensory cortex, Ins: insular cortex. The bar represents $200 \mu \mathrm{m}$ in $\mathrm{A}$ and $\mathrm{D}$, $120 \mu \mathrm{m}$ in $\mathrm{B}$ and $\mathrm{E}$, and $100 \mu \mathrm{m}$ in $\mathrm{C}$ and $\mathrm{F}$. 

cessing Structures. Chron Pain Manag 4: 130. DOI: 10.29011/2576-957X.100030

Within the amygdala (Figure 2A) intense pERK1/2 labeling was observed in the central nucleus. A robust pERK1/2 labeling is present in the lateral bed nucleus of the stria terminalis. Within the striatum pERK $1 / 2$ labeling was present in virtually all neurons (Figure 2B). In the nucleus accumbens, an intense pERK1/2 labeling was observed in some neurons of the shell subdivision while the core subdivision had a very low or no pERK1/2 labeling (Figure 2C). Intense pERK1/2 staining was present in the thalamus (Figure 2D), the habenula (Figure 2E), the ventral tegmental area (Figure 2F), the substantia nigra pars compacta (Figure 2G), and the periventricular nucleus of the hypothalamus (Figure 2H). Negative or very few cell staining was present in the control brain section (Figure 2I).
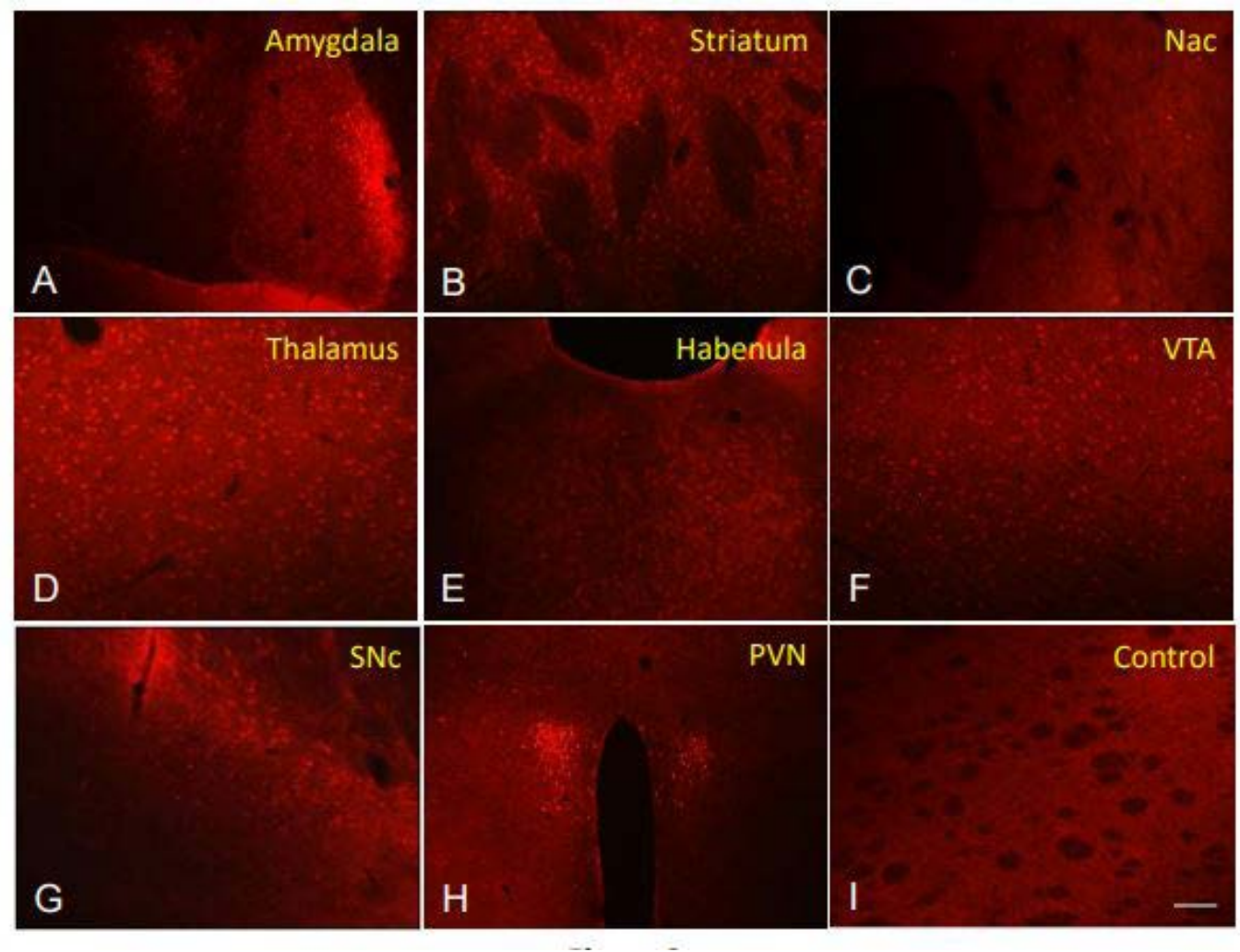

Figure 2: A micrograph showing the expression of pERK1/2 in different brain structures. Within the amygdala (A) intense pERK1/2 labeling is observed in the central nucleus. Robust pERK1/2 staining is also observed in the lateral bed nucleus of the stria terminalis. Most cells of the striatum expressed pERK1/2 labeling s (B). In the nucleus accumbens intense pERK1/2 labeling is present only in some neurons of the shell subdivision while the core subdivision is almost devoted to labeling (C). Intense pERK1/2 staining is located in neurons in the thalamus (D), the habenula (E), the ventral tegmental area $(2 \mathrm{~F})$, the substantia nigra compacta $(\mathrm{G})$, and the periventricular nucleus of the hypothalamus $(\mathrm{H})$. Control section is presented in (I) where a very few pERK1/2 stained cells are present. Nac: nucleus accumbens, SNc: substantia nigra parsa compacta, PVN: periventricular hypothalamic nucleus, VTA: ventral tegmental area. The bar represents $150 \mu \mathrm{m}$ in A, $120 \mu \mathrm{m}$ in B-G and I, and $200 \mu \mathrm{m}$ in H.

Within descending pain processing structures intense pERK1/2 labeling is present in neurons of all periaqueductal grey subdivisions (Figure 3A). In the dorsal raphe (Figure 3B) intense staining was observed in large neuronal cell bodies while a less intense one was present in other cell subtypes. A less intense pERK1/2 labeling was located in neurons within the rostral ventromedial medulla (Figure $3 \mathrm{C}$ ) and in neurons in the locus coerulus (Figure 3D). 
Citation: Omara-Reda H, Ouachikh O, Durif F, Hafidi A (2020) Acute Tramadol Administration Induces the Expression of pERK1/2 in Different Limbic and Pain Processing Structures. Chron Pain Manag 4: 130. DOI: 10.29011/2576-957X.100030

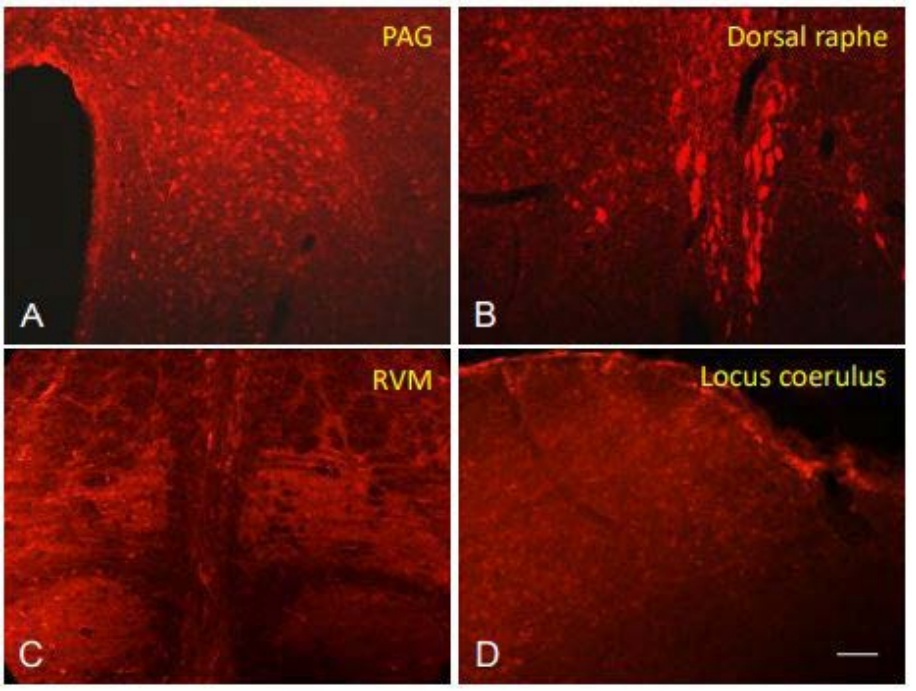

Figure 3: A micrograph showing the expression of $\mathrm{pERK} 1 / 2$ labeling in different descending pain processing structures. Intense pERK1/2 labeling is located in neurons of periaqueductal grey subdivisions (A). In the dorsal raphe (B), intense staining is present in large neuronal cell bodies while a less intense one is located in other cell subtypes. A less intense pERK1/2 labeling is located in neurons in the rostral ventromedial medulla (C) and the locus coerulus (D). PAG: periaqueductal grey, RVM: rostroventral medulla. The bar represents $120 \mu \mathrm{m}$ in A, B, and D, $150 \mu \mathrm{m}$ in C.

In the medullary dorsal horn pERK1/2 labeling was present within superficial laminae I and II (Figure 4A). At high magnification $\mathrm{pERK} 1 / 2$ positive neurons located within superficial lamina I-IIo and in some neurons within deeper lamina III (Figure 4B). pERK1/2 expression was also explored with the PKCg a specific marker of excitatory interneurons localized especially within internal lamina IIi and III [38-40]. PKCg presence delimited lamina IIo and separate it from outer lamina II. pERK1/2 was present in lamina I and IIo, while PKCg was located in lamina IIo and III mostly (Figure 4C). At high magnification (Figure 4D), there was no match between pERK1/2 and PKCg positive cells.

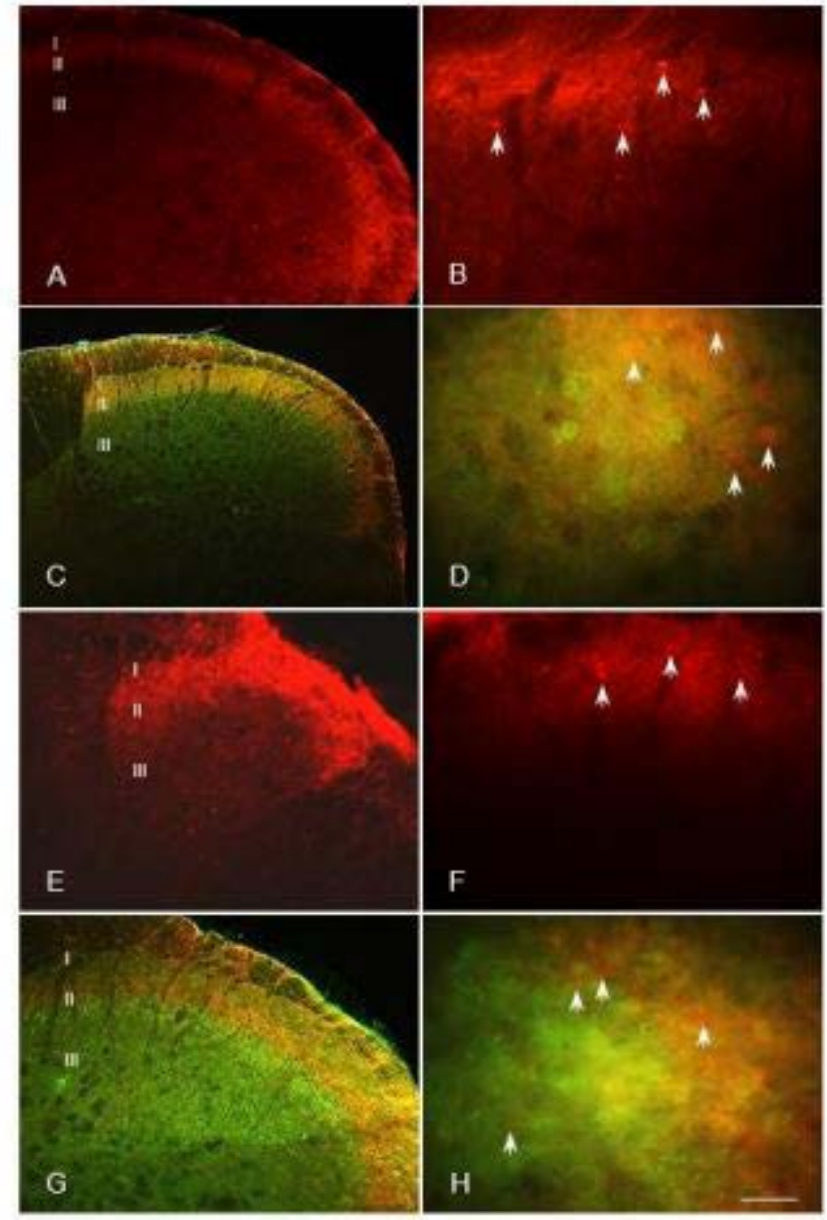

Figure 4: A micrograph showing the expression of pERK1/2 in medullary (A-D) and spinal (E-H) dorsal horns. In the medullary dorsal horn pERK1/2 labeling is present within superficial laminae I and II (A). pERK1/2 positive neurons are located within superficial lamina I-IIo and in some neurons within deeper lamina III (B). Double labeling using pERK1/2 and PKCg reveals a different pattern of labeling. pERK1/2 is present in lamina I and IIo, while PKCg was located in lamina IIi and III mostly (C). At high magnification (D), there was no match between $\mathrm{pERK} 1 / 2$ and $\mathrm{PKCg}$ positive cells. In the spinal dorsal horns pERK1/2 labeling is present within superficial laminae I and II (E). At high magnification pERK1/2 positive cells were observed in cells located within superficial laminae IIo and I (F) and some cells within lamina III. Double labeling using pERK1/2 and $\mathrm{PKCg}$ revealed the presence of $\mathrm{pERK} 1 / 2$ in lamina I and IIo, while PKCg was located in lamina III and III $(G)$. At high magnification, there was no match between $\mathrm{pERK} 1 / 2$ and PKCg positive cells $(\mathrm{H})$. IIi: internal lamina II, IIo: outer lamina II. The bar represents $250 \mu \mathrm{m}$ in A,C, E, G, 60 $\mu \mathrm{m}$ in $\mathrm{D}$ and $\mathrm{H}, 90 \mu \mathrm{m}$ in $\mathrm{B}$ and $\mathrm{F}$. 


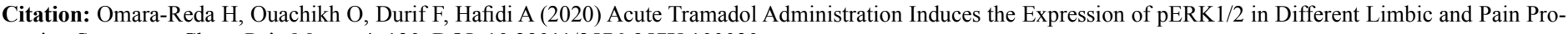
cessing Structures. Chron Pain Manag 4: 130. DOI: 10.29011/2576-957X.100030

In the spinal dorsal horns pERK1/2 labeling was present within superficial laminae I and II (Figure 4E). At high magnification pERK1/2 positive cells were observed in a few cells within superficial laminae (Figure 4F) and some cells within lamina III. Double labeling using pERK1/2 and PKCg revealed the presence of pERK1/2 in lamina I and IIo, while PKCg was located in lamina IIo and III (Figure 4G). At high magnification, there was no match between pERK1/2 and PKCg positive cells (Figure 4H). The pERK1/2 intensity of labeling in different brain structures is highlighted in Figure 5.

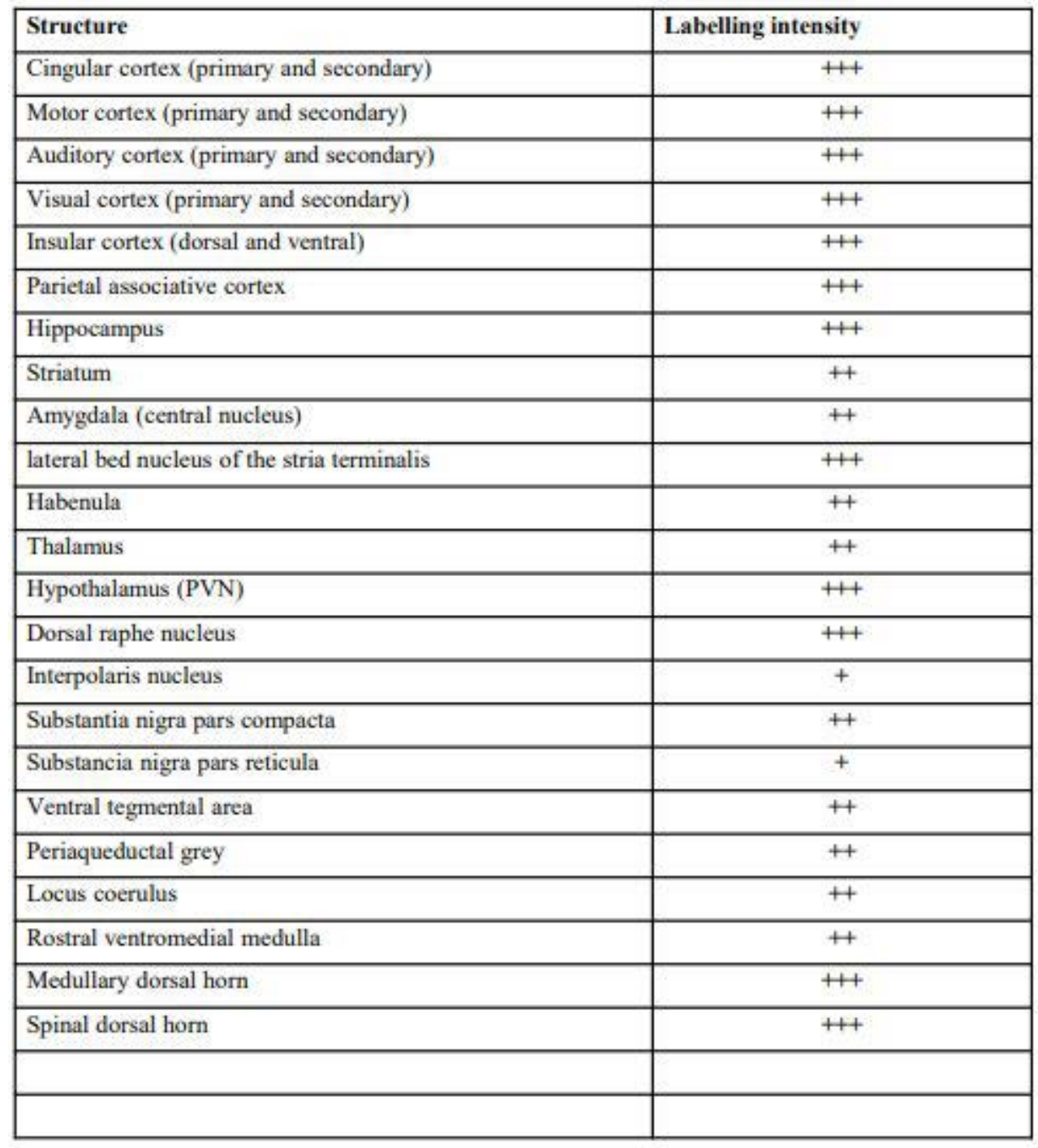

Figure 5: The table represents pERK1/2 labeling intensity in different brain structures. +++ robust staining that can extend to dendritic processes; ++ intense staining; + weak staining.

\section{Discussion}

The main results of the current study are that acute administration of tramadol induces intense pERK1/2 expression in different brain structures. Most of them are involved in addiction and pain regulation. Tramadol activated pERK1/2 expression in structures such as cortex, amygdala, hippocampus, striatum, ventral tegmental area, nucleus accumbens, which are implicated in the regulation of addiction. Besides, tramadol activated hypothalamic periventricular nucleus, periaqueductal gray, dorsal raphe, rostroventral medulla, locus coerulus, medullary, and spinal dorsal horns that are structured important in the regulation of pain. Therefore, the current results are following the dual reinforcing and pain effects of tramadol. 


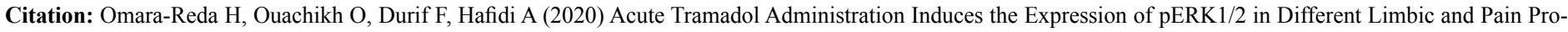
cessing Structures. Chron Pain Manag 4: 130. DOI: 10.29011/2576-957X.100030

Acute tramadol administration induced a robust pERK1/2 expression in different cerebral structures involved in addiction (nucleus accumbens, lateral bed nucleus of the stria terminalis, central amygdala, and deep prefrontal cortex, hippocampus, habenula, thalamus, VTA, SNc,) [41]. The expression of pERK1/2 in the current study is in accord with previous results showing that all drug of abuse administration induced the phosphorylation of ERK1/2 in nucleus accumbens, lateral bed nucleus of the stria terminalis, central amygdala and deep layers of the prefrontal cortex [32]. Conversely, the inhibition of ERK1/2 phosphorylation prevented conditioned place preference induced by cocaine, THC or MDMA [42-44]. This demonstrates an essential role of pERK1/2 in behavioral conditioning. Mice knockout in ERK1 are more sensitive to the rewarding properties of morphine, and this hypersensitivity correlated with a stimulus-dependent increase in pERK2 [45]. Last, tramadol-induced pERK1/2 was observed in structures that expressed high levels of MOR opioid receptor [46-50]. These regions included cerebral cortex, hippocampus, amygdala, thalamus, striatum, periaqueductal gray, locus coeruleus, raphe magnus, medullary and spinal dorsal horns. Activation of ERK1/2 participates to opioid addiction $[45,51,52]$. Although in the current study acute tramadol administration was used, pERK1/2 expression had a similar brain distribution as chronic morphine exposure with an intense signal in the locus coeruleus, caudate/ putamen [45], nucleus accumbens [53] and ventral tegmental area [51]. Tramadol effect could also be due to the activation of nonopioid receptors (GABAA, glycine, NMDA, adrenergic, nicotinic acetylcholine) or monoaminergic reuptake [4-8].

Pain sensation is regulated by two main ascending (lateral and medial) and descending pathways [54]. The lateral is responsible for the sensory aspects of pain and the medial for the emotional aspects of pain. Tramadol induced pERK1/2 expression in many pain-processing structures linked to both pain processing ascending and descending pathways. A robust pERK1/2 labeling was observed in somatosensory cortices, insular cortex, anterior cingulate cortex, hippocampus, lateral bed nucleus of the stria terminalis, amygdala, hypothalamus PVN, PAG, locus coerulus, and RVM. While a less intense pERK1/2 staining was observed in other pain processing structures. ERK signaling is very important in the pain process [31]. ERK activation is exclusively induced by noxious stimuli but not by innocuous stimuli [55]. Furthermore, pERK $1 / 2$ constitutes a biomarker for activated cells involved in pain signaling and nocifensive reflex [37,40,56]. In the case of tramadol, pERK1/2 activated cells might constitute cell subtypes that are involved in the inhibition of pain mechanism.

Interestingly, tramadol administration induced the expression of pERK1/2 in structures that have a high expression of MOR-1 (somatosensory cortex, hippocampus, amygdala, lateral bed nucleus of the stria terminalis, thalamus, hypothalamus PVN, the periaqueductal gray, the locus coeruleus, and raphe magnus, medullary and spinal dorsal horns), all of which are implicated in pain [54]. Morphine is known to modulate pain processing in both medial and lateral pain pathways.

At the level of medullary and spinal dorsal horns, tramadol induced a robust pERK $1 / 2$ expression especially in superficial lamina II especially outer region IIo. This lamina is known to regulate the pain process since it receives both ascending and descending pain projections [57]. Besides, lamina II contains also a high expression of MOR receptors [46-50]. pERK1/2 did not colocalize in PKCg excitatory cells that play an important role in allodynia $[37,38]$. The activation of ERK1/2 in medullary and dorsal horns constitutes a pain biomarker [37,56] and participates in the generation and maintenance of pain. The phosphorylation of ERK $1 / 2$ constitutes a marker for neurons activated by nociceptive stimuli. The inhibition of ERK1/2 activation blocked or alleviated pain [58-60]. Therefore, tramadol induced pERK1/2 expression in cell subtype within lamina IIo that are involved in pain inhibition.

\section{Conclusion}

Tramadol induced the expression of pERK1/2 in cerebral structures that participate to both pain process and addiction which is following its painkiller and reinforcing effect.

\section{Acknowledgments}

This study was funded by Clermont Auvergne University and all authors declare that there is no conflict of interest.

\section{References}

1. Grond S, Sablotzki A (2004) Clinical pharmacology of tramadol. Clin Pharmacokinet 43: 879-923.

2. Codd EE, Shank RP, Schupsky JJ, Raffa RB (1995) Serotonin and norepinephrine uptake inhibiting activity of centrally acting analgesics: structural determinants and role in antinociception. J Pharmacol Exp Ther 274: 1263-1270.

3. Bloms-Funke P, Dremencov E, Cremers TIFH, Tzschentke TM (2011) Tramadol increases extracellular levels of serotonin and noradrenaline as measured by in vivo microdialysis in the ventral hippocampus of freely-moving rats. Neuroscience Letters 490: 191-195.

4. Faron-Górecka A, Kuśmider M, Inan SY, Siwanowicz J, Piwowarczyk T, et al. (2004) Long-term exposure of rats to tramadol alters brain dopamine and alpha 1-adrenoceptor function that may be related to antidepressant potency. Eur J Pharmacol 501: 103-110.

5. Shiraishi M, Minami K, Uezono Y, Yanagihara N, Shigematsu A, et al. (2002) Inhibitory effects of tramadol on nicotinic acetylcholine receptors in adrenal chromaffin cells and in Xenopus oocytes expressing alpha 7 receptors. Br J Pharmacol 136: 207-216.

6. Hara K, Minami K, Sata $T$ (2005) The effects of tramadol and its metabolite on glycine, gamma-aminobutyric acidA, and N-methyl-Daspartate receptors expressed in Xenopus oocytes. Anesthesia Analg 100: $1400-1405$

7. Katsuki R, Fujita T, Koga A, Liu T, Nakatsuka T, et al. (2006) Tramadol, but not its major metabolite (mono-O-demethyl tramadol) depresses compound action potentials in frog sciatic nerves. $\mathrm{Br} \mathrm{J}$ Pharmacol 149 319-327. 
Citation: Omara-Reda H, Ouachikh O, Durif F, Hafidi A (2020) Acute Tramadol Administration Induces the Expression of pERK1/2 in Different Limbic and Pain Processing Structures. Chron Pain Manag 4: 130. DOI: 10.29011/2576-957X.100030

8. Bravo L, Mico JA, Berrocoso E (2017). Discovery and development of tramadol for the treatment of pain. Expert Opin Drug Discov 12: $1281-1291$.

9. Preston $\mathrm{KL}$, Jasinski DR, Testa M (1991) Abuse potential and pharmacological comparison of tramadol and morphine. Drug Alcohol Depend 27: 7-17.

10. Freye E, Levy J (2000) Acute abstinence syndrome following abrupt cessation of long-term use of tramadol (Ultram): a case study. Eur $\mathrm{J}$ Pain 4: 307-311.

11. Leo RJ, Narendran R, DeGuiseppe B (2000) Methadone detoxification of tramadol dependence. J Subst Abuse Treat 19: 297-299.

12. Thomas AN, Suresh $M(2000)$ Opiate withdrawal after tramadol and patient-controlled analgesia. Anaesthesia 55: 826-827.

13. Yates WR, Nguyen MH, Warnock JK (2001) Tramadol dependence with no history of substance abuse. Am J Psychiatry 158: 964.

14. Sprague JE, Leifheit M, Selken J, Milks MM, Kinder DH, et al. (2002) In vivo microdialysis and conditioned place preference studies in rats are consistent with abuse potential of tramadol. Synapse 43: 118-121.

15. Tzschentke TM, Bruckmann W, Friderichs E (2002) Lack of sensitization during place conditioning in rats is consistent with the low abuse potential of tramadol. Neuroscience letters, 329: 25-28.

16. Barsotti CE, Mycyk MB, Reyes J (2003) Withdrawal syndrome from tramadol hydrochloride. Am J Emerg Med 21: 87-88.

17. Senay EC, Adams EH, Geller A, Inciardi JA, Munoz A, et al. (2003) Physical dependence on Ultram (tramadol hydrochloride): both opioidlike and atypical withdrawal symptoms occur. Drug Alcohol Depend 69: 233-241.

18. Watson WA, Litovitz TL, Rodgers Jr GC, Schwartz WK, Youniss J, et al. (2003) 2002 annual report of the American Association of Poison Control Centers Toxic Exposure Surveillance System. Am J Emerg Med 21: 353-421.

19. Zacny JP (2005) Profiling the subjective, psychomotor, and physiological effects of tramadol in recreational drug users. Drug Alcohol Depend 80: 273-278.

20. Epstein DH, Preston KL, Jasinski DR (2006) Abuse liability, behavioral pharmacology, and physical-dependence potential of opioids in humans and laboratory animals: lessons from tramadol. Biol Psychol 73: 90-99.

21. Carroll CP, Walsh SL, Bigelow GE, Strain EC, Preston KL (2006) Assessment of agonist and antagonist effects of tramadol in opioiddependent humans. Exp Clin Psychopharmacol 14: 109-120.

22. Lofwall MR, Walsh SL, Bigelow GE, Strain EC (2007) Modest opioid withdrawal suppression efficacy of oral tramadol in humans. Psychopharmacology (Berl) 194: 381-393.

23. Nakamura A, Narita M, Miyoshi K, Shindo K, Okutsu D, et al. (2008) Changes in the rewarding effects induced by tramadol and its active metabolite M1 after sciatic nerve injury in mice. Psychopharmacology (Berl) 200: 307-316.

24. Spiller HA, Scaglione JM, Aleguas A, Foster H, Durback-Morris L, et al. (2010) Effect of scheduling tramadol as a controlled substance on poison center exposures to tramadol. Ann Pharmacother 44: 10161021.

25. Babalonis S, Lofwall MR, Nuzzo PA, Siegel AJ, Walsh SL (2013) Abuse liability and reinforcing efficacy of oral tramadol in humans. Drug Alcohol Depend 129: 116-124.

26. Zhang H, Liu Z (2013) The investigation of tramadol dependence with no history of substance abuse: a cross-sectional survey of spontaneously reported cases in Guangzhou City, China. Biomed Res Int 2013: 283425.
27. Cha HJ, Song MJ, Lee KW, Kim EJ, Kim YH, et al. (2014) Dependence potential of tramadol: behavioral pharmacology in rodents. Biomol Ther 22: 558-562.

28. Dunn KE, Bergeria CL, Huhn AS, Strain EC (2019) A Systematic Review of Laboratory Evidence for the Abuse Potential of Tramadol in Humans. Front Psychiatry 10: 704.

29. Giovannini MG (2006) The role of the extracellular signal-regulated kinase pathway in memory encoding. Rev Neurosci 17: 619-634.

30. Zamora-Martinez ER, Edwards S (2014) Neuronal extracellular signalregulated kinase (ERK) activity as marker and mediator of alcohol and opioid dependence. Front Integr Neurosci 8: 24.

31. Kondo M, Shibuta I (2020) Extracellular signal-regulated kinases (ERK) 1 and 2 as a key molecule in pain research. J Oral Sci 62: 147-149.

32. Valjent E, Pagès C, Hervé D, Girault JA, Caboche J (2004) Addictive and non-addictive drugs induce distinct and specific patterns of ERK activation in mouse brain. Eur J Neurosci 19: 1826-1836.

33. Lu L, Koya E, Zhai H, Hope BT, Shaham Y (2006) Role of ERK in cocaine addiction. Trends Neurosci 29: 695-703.

34. Zhai H, Li Y, Wang X, Lu L (2008) Drug-induced alterations in the extracellular signal-regulated kinase (ERK) signalling pathway: implications for reinforcement and reinstatement. Cell Mol Neurobiol 28: 157-172.

35. Pascoli V, Cahill E, Bellivier F, Caboche J, Vanhoutte P (2014) Extracellular signal-regulated protein kinases 1 and 2 activation by addictive drugs: a signal toward pathological adaptation. Biol Psychiatry 76: 917-926.

36. Agoglia AE, Sharko AC, Psilos KE, Holstein SE, Reid GT, et al. (2015) Alcohol alters the activation of ERK1/2, a functional regulator of binge alcohol drinking in adult C57BL/6J mice. Alcohol Clin Exp Res 39: 463475 .

37. Dieb W, Alvarez P, Hafidi A (2015) PKCy-positive neurons gate light tactile inputs to pain pathway through pERK1/2 neuronal network in trigeminal neuropathic pain model. J Oral Facial Pain Headache 29: 70-82.

38. Ouachikh O, Hafidi A, Boucher Y, Dieb W (2018) Electrical Synapses are Involved in Orofacial Neuropathic Pain. Neuroscience 382: 69-79.

39. Polgár E, Fowler JH, McGill MM, Todd AJ (1999) The types of neuron which contain protein kinase $\mathrm{C}$ gamma in rat spinal cord. Brain Res 833: 71-80.

40. Dieb W, Hafidi A (2015) Mechanism of GABA involvement in posttraumatic trigeminal neuropathic pain: activation of neuronal circuitry composed of PKCY interneurons and pERK1/2 expressing neurons. Eur J Pain 19: 85-96.

41. Koob GF, Sanna PP, Bloom FE (1998) Neuroscience of addiction. Neuron 21: 467-476.

42. Valjent E, Corvol JC, Pages C, Besson MJ, Maldonado R, et al. (2000) Involvement of the Extracellular Signal-Regulated Kinase Cascade for Cocaine-Rewarding Properties. J Neurosci 20: 8701-8709.

43. Valjent E, Pages C, Rogard M, Besson MJ, Maldonado R, et al. (2001) Delta 9-tetrahydrocannabinol-induced MAPK/ERK and Elk-1 activation in vivo depends on dopaminergic transmission. Eur $\mathrm{J}$ Neurosci 14: 342-352.

44. Salzmann J, Marie-Claire C, Le Guen S, Roques BP, Noble F (2003) Importance of ERK activation in behavioral and biochemical effects induced by MDMA in mice. Br J Pharmacol 140: 831-838. 
Citation: Omara-Reda H, Ouachikh O, Durif F, Hafidi A (2020) Acute Tramadol Administration Induces the Expression of pERK1/2 in Different Limbic and Pain Processing Structures. Chron Pain Manag 4: 130. DOI: 10.29011/2576-957X.100030

45. Mazzucchelli $C$, Vantaggiato $C$, Ciamei A, Fasano S, Pakhotin $P$, et al (2002) Knockout of ERK1 MAP kinase enhances synaptic plasticity in the striatum and facilitates striatal-mediated learning and memory. Neuron 34: 807-820.

46. Mansour A, Fox CA, Thompson RC, Akil H, Watson SJ (1994) $\mu$-Opioid receptor mRNA expression in the rat CNS: comparison to mu-receptor binding. Brain Res 643: 245-265.

47. Arvidsson U, Riedl M, Chakrabarti S, Lee JH, Nakano AH, et al. (1995) Distribution and targeting of a mu-opioid receptor (MOR1) in the brain and spinal cord. J Neurosci 15: 3328-3341.

48. Ding YQ, Kaneko T, Nomura S, Mizuno N (1996) Immunohistochemical localization of mu-opioid receptors in the central nervous system of the rat. J Comp Neurol 367: 375-402.

49. Abbadie C, Pan YX, Pasternak GW (2000) Differential distribution in rat brain of mu opioid receptor carboxy terminal splice variants MOR1C-like and MOR-1-like immunoreactivity: evidence for region-specific processing. J Comp Neurol 419: 244-256.

50. Zhang Y, Pan YX, Kolesnikov Y, Pasternak GW (2006) Immunohistochemical labeling of the mu opioid receptor carboxy terminal splice variant mMOR-1B4 in the mouse central nervous system. Brain Res 1099: 33-43.

51. Berhow MT, Hiroi N, Nestler EJ (1996) Regulation of ERK (extracellular signal regulated kinase), part of the neurotrophin signal transduction cascade, in the rat mesolimbic dopamine system by chronic exposure to morphine or cocaine. J Neurosci 16: 4707-4715.

52. Eitan S, Bryant CD, Saliminejad N, Yang YC, Vojdani E, et al. (2003) Brain region-specific mechanisms for acute morphine-induced mitogen-activated protein kinase modulation and distinct patterns of activation during analgesic tolerance and locomotor sensitization. J Neurosci 23: 8360-8369.
53. Liu S, Bubar MJ, Lanfranco MF, Hillman GR, Cunningham KA (2007) Serotonin2C receptor localization in GABA neurons of the rat medial prefrontal cortex: implications for understanding the neurobiology of addiction. Neuroscience 146: 1677-1688.

54. Millan MJ (2002) Descending control of pain. Prog Neurobiol 66: 355474.

55. Ma W, Quirion R (2005) The ERK/MAPK pathway, as a target for the treatment of neuropathic pain. Expert Opin Ther Targets 9: 699-713.

56. Ji RR, Baba H, Brenner GJ, Woolf CJ (1999) Nociceptive-specific activation of ERK in spinal neurons contributes to pain hypersensitivity. Nat Neurosci 2: 1114-1119.

57. Todd AJ (2015) Plasticity of inhibition in the spinal cord. Handb Exp Pharmacol 227: 171-190.

58. Ouachikh O, Dieb W, Durif F, Hafidi A (2014) Anterior ventral tegmental area dopaminergic neurons are not involved in the motivational effects of bromocriptine, pramipexole and cocaine in drug-free rats. Behav Brain Res 262: 1-7.

59. Lim EJ, Jeon HJ, Yang GY, Lee MK, Ju JS, et al. (2007) Intracisternal administration of mitogen-activated protein kinase inhibitors reduced mechanical allodynia following chronic constriction injury of infraorbital nerve in rats. Prog Neuropsychopharmacol Biol Psychiatry 31: 13221329

60. Qiao LY, Gulick MA (2007) Region-specific changes in the phosphorylation of ERK1/2 and ERK5 in rat micturition pathways following cyclophosphamide-induced cystitis. Am J Physiol Regul Integr Comp Physiol 292: R1368-R1375. 